UDK: 343.81:[616.98:578.834(497.115)

doi: $10.5937 /$ crimen2103301D

PREGLEDNI ČLANAK

PRIMLJEN / PRIHVAĆEN: 25.10.2021. / 15.12.2021.

\author{
Nebojša Draganović* \\ Penitentiary in Sremska Mitrovica
}

\title{
PREVENTING THE SPREAD OF COVID-19 INFECTION AT THE PENITENTIARY FACILITY IN SREMSKA MITROVICA
}

\begin{abstract}
The article points out how the largest penitentiary in the country and one of the largest institutions of this type of facility has faced the Covid 19 pandemic from the outbreak to the present days. Although the Institution was relatively unprepared for the infection of this extent, in cooperation with the competent health authorities and based on the decisions of the competent authorities in the Administration for the Enforcement of Penal Sanctions, the rapid spread of the disease was prevented and satisfactory results have been achieved so far. At one point, the number of positive cases for the virus was 380 , but luckily, the symptoms were lighter. The basic method of action at that point was strict isolation and thanks to its application, no convicted person in the institution has fall for the disease. It is interesting that persons deprived of their liberty during the pandemic were engaged in the production of protective masks not only for the purposes of the institution within the Administration for the Enforcement of Penal Sanctions, but also for the needs of health care institutions in Sremska Mitrovica and throughout the Republic of Serbia.
\end{abstract}

Key words: pandemic, isolation, therapy, vaccination, convicted persons.

\section{INTRODUCTION}

The Penitentiary in Sremska Mitrovica is one of the largest prisons in Southeast Europe. It was created in the period 1895 - 1900 by the decree of Francis Joseph I and at the suggestion of the then Ban Kuen Hedervari. It was one of the most modern buildings in the then Austro-Hungarian monarchy with steam heating, electric lighting and developed industry, agriculture and livestock. This Penitentiary has always had more convicts in large numbers, given the actual capacity, so it was difficult to maintain the level of hygiene and health care at the required level.

The appearance of infectious diseases and the fight against them is not new within these walls. Throughout its history, tuberculosis, malaria, dysentery, typhus and cholera ruled in the penitentiary at that time. At the end of the 19th century,

* Deputy Warden, nebojsa.draganovic@uiks.gov.rs . 
there was a serious spread of malaria among convicts who were a pillar of flood defense at that time in Sremska Mitrovica. The activity of convicted persons increased after the withdrawal of the Sava River into its trough. Wetland soil remained, suitable for the development of malaria-transmitting mosquitoes. Suddenly, a large number of people suffering from malaria appeared, and the mortality rate was high. Fate wanted the convicted person Andrija Anik to be in the prison in Sremska Mitrovica just then, who before coming to the prison worked on finding a cure for malaria and received a Certificate of Recognition from the Institute of Public Health in $\mathrm{Ru}$ menci on August 27, 1939. Thanks to this discovery, his sentence was forgiven. The drug was called „RADIZIN”.

The worst was in the Penitentiary in Sremska Mitrovica during the great wars, when man as a human being was not taken into account and when measures for the protection of life were not applied. At that time, there were many deaths due to the neglect of life and health by the first Austro-Hungarian state and later the Independent State of Croatia. The victims of neglect were mostly Serbs.

It is interesting to say that Milan Jovanović Batut was born in Sremska Mitovica in 1847. He graduated from the Medical Faculty in Vienna in 1878 and dedicated his research to hygiene and bacteriology. He studied in Paris, Munich, London and Berlin, and he knew Louis Pasteur personally. He later founded the Medical Faculty in Belgrade. Today, the Institute of Public Health of Serbia is named after him and is the leading institution for the fight against the Covid 19 pandemic.

\section{MEASURES TAKEN TO PROTECT PRISONERS AND EMPLOYEES}

The Covid 19 pandemic was received unpreparedly by the Sremska Mitrovica Penitentiary. No one expected that a flu-like infection would have planetary proportions, that is, it would turn into a pandemic with a large number of infected and dead people. At the time of the pandemic, we counted 2,000 convicts in penal conditions and 630 employees. With the numerous instructions of the director of the Administration for the Enforcement of Penal Sanctions, the warden of the Central Prison Hospital in Belgrade, but above all the Institute of Public Health of Serbia „Dr Milan Jovanović Batut” and the Infectious Diseases Clinic of the Clinical Center of Serbia, and with our maximum efforts, we managed to strongly oppose the impending plague.

We have prepared facilities for the needs of isolation or quarantine for the infected and raised the work of the health service of the institute to an extremely high level. We have provided enough protective equipment: non-contact thermometers, protective masks made of certified materials, spacesuits, nipples, hats, coats, visors, but also disinfectants and a sufficient amount of medicines for potentially infected convicts. We determined the points for entering in the Penitentiary where our responsible and conscientious workers worked. No one could pass unless his temperature was measured, if he did not pass through the des-barrier and without protective equipment. We have also provided a large number of rapid antigen tests 
and finally enough vaccines from several manufacturers, so we have successfully vaccinated over $70 \%$ of our protégés. We managed to maintain the system at a high level with a certain number of ill convicts, who had milder symptoms and received adequate therapy. We also had a number of infected convicts with an asymptomatic clinical picture of COVID 19. Regardless of the clinical picture, the infected were in quarantine, isolated for 14 days. Vaccination is on a voluntary basis and all those who applied were vaccinated. All these events around the COVID 19 Pandemic were a great challenge for us at the Penitentiary in Sremska Mitrovica, not only for the employed, but also for persons deprived of their liberty.

The first information about the existing seasonal flu, but also the appearance of a new corona virus later called Covid 19, we received on February 14, 2020. in the form of an order from the director of the Administration for the Enforcement of Penal Sanctions, Dejan Carević. The order states that all managers of Penitentiary Institutions and District Prisons must be informed about the new situation and strengthen hygiene and disinfection measures in the institutions they manage. Shortly afterwards, instructions and recommendations for the application of protection measures by the Institute of Public Health of Serbia „Dr Milan Jovanovic Batut” received regarding the new situation as well as the procedure in case of persons with symptoms of respiratory diseases.

In order to prevent a possible epidemic of "Corona virus" in penal conditions, the Director of the Administration for the Enforcement of Penal Sanctions issues a new order to all wardens of penitentiaries and district prisons on March 11, 2020, stating all measures ordered by the Institute of Public Health of Serbia „Dr Milan Jovanovic Batut"and the Infectious Diseases Clinic of the Clinical Center of Serbia.

The measures mention, among other things, the procurement of a sufficient number of non-contact thermometers, the required amount of disinfectants, and the construction of checkpoints. No one with a high temperature is allowed to enter the institution. Also, newly arrived convicts must be placed in the Penitentiary for two weeks with increased health supervision. They are postponed until further outof-prison benefits with the possibility of receiving packages, all group visits to the Penitentiary are postponed and escorts of convicts are reduced, more frequent hand washing, disinfection of floors, equipment, work surfaces and protective masks and gloves are recommended.

According to the following order, the Director of the Administration for the Enforcement of Penal Sanctions prohibits visits to convicts for 14 days, so that detainees can be visited by lawyers for half an hour with the application of all protection measures if a trial is scheduled for the next seven days. In order for an employed worker to enter on the Penitentiary, he first had to wear a mask, disinfect hands and shoes at the entry point, measure temperature with a non-contact thermometer and only then go to the workplace.

If the employees of the Penitentiary in Sremska Mitrovica were diagnosed with Covid 19 infection based on a doctor's prescription, they would be sent on sick leave for at least 14 working days, which was paid 100\%. Employees who were in direct contact with infected persons (wife, husband, father, mother, etc.) based on 
the recommendation of the competent authorities, were in home isolation for up to seven days. After the expiration of the isolation, a quick antigen test was performed, and only after a negative result, the employee returned to his workplace. Also, we took into account the employees of the Institute who have been suffering from chronic diseases for a long time (Diabetes-diabetes mellitus, Asthma-asthma, etc.), we introduced shift work where possible and minimized the number of employees in working-rooms.

People trained to work at checkpoints also wear masks and gloves, and in critical places, visors and protective suits. Critical places are the reception of new convicts, detainees and offenders, but also the facility for the reception of ill convicts (hospitals) and the kitchen with dining room. At these places, disinfection of premises and objects is performed every two hours.

We were in constant contact with the Administration for the Enforcement of Penal Sanctions, the Special Prison Hospital Belgrade, the Institute of Public Health of Serbia "Dr Milan Jovanovic Batut”, the Infectious Diseases Clinic of the Clinical Center and the Institute of Public Health in Sremska Mitrovica.

At the very beginning of the Covid 19 pandemic, there was a great problem in the procurement of protective equipment, no one had it, and huge quantities were needed. Considering that there is a sewing plant "Textile Studio" in the Penitentiary in Sremska Mitrovica, the regular program of work in textile production was stopped and all forces were redirected on March 12, 2020. for the production of protective masks, protective suits, protective caps, coats, nipples and other protective equipment. At that time, twenty-two convicts were hired who underwent certified training in the textile studio and a large number of volunteers, convicts who reported to work on their own in order to speed up the production of protective equipment. Under the expert supervision of instructors, up to 3,800 pieces of protective masks were produced daily in a period when they could not be obtained anywhere.

We managed to satisfy our needs, the needs of the Administration for the Enforcement of Penal Sanctions, the Central Prison Hospital in Belgrade, as well as other penitentiaries and district prisons. The Penitentiary in Nis and the Penitentiary for Women in Požarevac were also engaged in the production of protective equipment. To date, we have produced almost half a million pieces of various protective equipment to combat the Covid 19 pandemic.

To our satisfaction, we forwarded a numerous of masks to the City Hospital and other health institutions in Sremska Mitrovica because they did not have them and the hospital was full of infected patients.

At the beginning of December 2020, we learned from a member of the security service from the semi-open department of "Zelengora” that the convicted person would not report that he had lost his sense of taste and smell, so that he would not be banned from receiving packages. He did not have a fever and subjectively felt good. The mentioned convicted person tried to avoid isolation or quarantine for 14 days and thus keep certain benefits that follow him in regular circumstances. 
It was an alarm on the basis of which the warden Aleksandar Alimpić ordered that all convicts be tested with a quick antigen test, regardless of whether they have symptoms of infection or not. After the organized action in the entire Penitentiary, there were about 200 positive persons in the semi-open wards and about 180 convicts in the closed part of the institution. These were infected persons without a clinical picture or with a weak clinical picture. We gave the appropriate therapy to everyone who needed it. We determined the room for isolation - quarantine, both in the semi-open and open and in the closed part of the institution, and accommodated the infected, intensified the maximum measures of disinfection and health care and literally froze the entire system for 14 days.

The vast majority of convicts who were isolated due to the infection took the Covid 19 pandemic seriously and actively and conscientiously participated in the implementation of measures to protect life and health in this emergency situation. They showed their responsible behavior with a great response to vaccination, but also with their relentless work in the "Textile Studio" on the production of protective equipment to combat the Covid 19 pandemic. It can be concluded that convicts showed established, everyday life in the Penitentiary. They accepted the fact that the entire population is in crisis and uncertainty due to the Covid 19 pandemic, based on interviews with people employed by the Office as well as on the media available to them.

In the implementation of the measure of isolation in convicted persons, no cases of extreme dysfunctional behavior have been registered, which would be a consequence of the manifestation of inadequate emotions such as unhealthy anger and depression. Feelings of sadness and helplessness were most often linked to the circumstance of not being able to make normal contact with family members, when visits were forbidden. Later, when visits were approved with appropriate measures, it often happened that some convicts suggested to their family members not to visit during the pandemic and not to be exposed to the danger of infection. During the isolation, convicts most often complained about boredom, i. e. the absence of certain activities that enabled them to spend time in a structured way in the Penitentiary: daily going to sports fields and staying two hours in the fresh air, working in metal, wood and other facilities, participation in certain group forms of work, specialized programs, sections, etc.

Convicted persons were quarantined with food brought to an improvised dining room, and part of the health service worked only in quarantine in full protective equipment. None of the employees entered the closed part of the Penitentiary except in emergencies, viz. when the presence was necessary. The Security Service was exempted. Also, no one could move without protective equipment. After the expiration of the isolation, several more sporadic cases of infection appeared, so that on January 22, 2021, there were no more positives for the corona virus.

The Health Service at the Penitentiary in Sremska Mitrovica consists of the Head of the Health Service, five full-time general practitioners, three general practitioners under contract and ten specialist specialists under contract. Twenty-two medical technicians are also permanently employed. In the Penitentiary there is a 
facility for the reception of sick convicts and two clinics, while in the external wards there are also two clinics. If the health problem is bigger, it is solved by sending the sick convicted person to the Special Prison Hospital in Belgrade, the Hospital in Sremska Mitrovica or to a specialized health institution if, according to the doctor's assessment, the current situation requires it.

So far, about 540 convicts have been treated for this infection, including 50 convicts with previously diagnosed chronic diseases (Diabetes mellitus, Asthma, AIDS-Syndrome d'immunodéficience acquise, Heart disease - CVD, Jaundice - icterus, Tumor-Carcinoma, etc.). The total number of chronically ill convicts in the Penitentiary in Sremska Mitrovica is over 300, some are accommodated in regular accommodation with prescribed therapy and some are in the facility for accommodation of ill convicts, under the expert supervision of specialists.

All Covid 19-positive convicts received adequate therapy. Vitamin therapy was given to everyone and antipyretics, antibiotics and corticosteroids were prescribed by specialists from the Covid Center of the General Hospital in Sremska Mitrovica based on the clinical picture, laboratory findings and roentgen (X-ray) findings.

It also happened in this Penitentiary that the convicted person succumbed to a disease from which he had been suffering for a long time, but so far in no case, based on the doctor's report, was the cause of death Covid infection 19.

Due to the new situation, we have provided a sufficient amount of protective equipment and disinfectants, medicines, a large amount of rapid antigen tests and vaccines from several manufacturers.

In March 2021, we performed a voluntary vaccination of 826 convicts with "Astra Zeneka" vaccine, and then at the beginning of May with 360 „Sinofarm” vaccine, all without complications. Vaccination continued and was organized twice a month for all convicts who wanted it.

Currently, over $70 \%$ of the convicted population has been vaccinated and we do not have critically ill cases since. Convicts who wanted it were also vaccinated against seasonal flu. Vaccination was also organized for the employees of the Penitentiary in Sremska Mitrovica, willingly. Based on the favorable epidemiological situation in Penitentiary Institutions and District Prisons, on May 12, 2021, the Director of the Administration for the Enforcement of Penal Sanctions Dejan Carević lifts the ban on the use of out-of-prison benefits and employment for persons serving prison sentences vaccinated against Covid virus 19 and persons who have undergone the virus in accordance with certain criteria specified in the order. Convicted persons were provided with a telephone conversation more than usual and visual contact with their families via the Internet (Skype) provided. At the Penitentiary in Sremska Mitrovica, we are still seriously implementing protection measures against the spread of the Covid 19 pandemic, and we are resolving the occurrence of sporadic cases of infection in convicts who are asymptomatic or with mild symptoms by the established method and without problems. Every convicted person who wants and applies for vaccination will be vaccinated as soon as possible. 


\title{
CONCLUSION
}

This Covid 19 pandemic from the very beginning until today, leaves us a great experience in the fight against infectious and contagious diseases, new knowledge about the behavior of convicts in isolation and work organization in the absence of more employees due to infection and absence of persons who were in contact with an infected person.

This huge new experience shows us, above all, how to behave professionally and responsibly in extreme, unusual situations, and in order to protect health, both our own and the health of the people around us.

\author{
Nebojša Draganović* \\ Kazneno-popravni zavod u Sremskoj Mitrovici
}

\section{KAKO SPREČAVAMO ŠIRENJE COVID-19 INFEKCIJE U KAZNENO-POPRAVNOM ZAVODU U SREMSKOJ MITROVICI}

\section{REZIME}

U tekstu je ukazano na to kako se najveći kazneno-popravni zavod u zemlji i jedna od najvećih ustanova ovog tipa suočila sa pandemijom Covid 19 od saznanja za novu zaraznu bolest do ovih dana. Iako je Zavod bio relativno nespreman za zarazu ovog obima, u saradnji sa nadležnim zdravstvenim vlastima i na osnovu odluka nadležnih u Upravi za izvršenje krivičnih sankcija sprečeno je brzo širenje bolesti i do sada su postignuti zadovoljavajući rezultati. $U$ jednom trenutku broj pozitivnih na virus iznosio je tri stotine osamdeset, ali na sreću simptomi su bili lakši. U momentu nastanka pandemije brojali smo 2.000 osuđenih lica u penalnim uslovima i 630 zaposlenih radnika. Uz stalne instrukcije direktora Uprave za izvršenje krivičnih sankcija, upravnika Centralne zatvorske bolnice u Beogradu ali pre svega Instituta za javno zdravlje Srbije „Dr Milan Jovanović Batut” i Infektivne Klinike Kliničkog centra Srbije i uz naše maksimalne napore uspeli smo da se snažno suprotstavimo predstojećoj pošasti. Osnovni metod delovanja u tom trenutku bila je stroga izolacija i zahvaljujući njenoj primeni do sada ni jedno osuđeno lice u zavodu nije podleglo ovoj bolesti. Trenutno je vakcinisano preko 70\% osuđeničke populacije i nemamo teško obolelih. Zanimljivo je da su lica lišena slobode tokom pandemije angažovana na proizvodnji zaštitinih maski ne samo za potrebe zavoda u okviru Uprave za izvršenje krivičnih sankcija, nego i za potrebe zdravstvenih ustanova u Sremskoj Mitrovici i širom Republike Srbije.

Ključne reči: Pandemija, izolacija, terapija, vakcinacija, osuđena lica.

* Zamenik upravnika, nebojsa.draganovic@uiks.gov.rs . 